\title{
Sifat Melawan Hukum Dalam Tindak Pidana Korupsi
}

\author{
Idi Amin ${ }^{1}$ \\ Fakultas Hukum Universitas Mataram, \\ Jln. Majapahit No. 62 Mataram 83125, \\ Telp. (0370), 633035, Fax. 626954 \\ Email: idiamin@mail.com
}

\begin{abstract}
ABSTRAK
Korupsi merupakan perbuatan tercela dan bentuk dari penyakit sosial masyarakat, sehingga korupsi dikategorikan sebagai suatu tindak pidana (Straafbaarfeit). Diberlakukannya Undang-Undang Nomor 31 Tahun 1999 sebagai penyempurnaan atas Undang-Undang Nomor 3 Tahun 1971 tentang pemberantasan Tindak Pidana Korupsi. Undang-Undang Nomor 31 Tahun 1999 disempurnakan kembali dan diubah dengan Undang-Undang Nomor 20 Tahun 2001. Penyempurnaan ini dimaksud untuk lebih menjamin kepastian hukum, menghindari keragaman penafsiran hukum dan memberikan perlindungan terhadap hak-hak sosial dan ekonomi masyarakat, serta perlakuan yang adil dalam memberantas tindak pidana korupsi. Berdasarkan pokok pemikiran diatas maka dapat dirumuskan permasalahan yaitu bagaimanakah sifat melawan hukum dalam tindak pidana korupsi. Penelitian ini menggunakan penelitian hukum normatif, dengan menggunakan metode pendekatan perundangundangan dan konseptual. Data yang digunakan adalah data sekunder yang merupakan bahan hukum primer, bahan hukum sekunder, bahan hukum tersier, maka teknik pengumpulan data yang digunakan yaitu studi kepustakaan dan dokumenter dari data sekunder yang telah dianalisis.

Dari hasil penelitian diperoleh kesimpulan bahwa secara konsepsional tentunya sifat melawan hukum seperti diatur dalam Pasal 2 ayat (1) Undang-undang No. 31 Tahun 1999 hanya menganut ajaran sifat melawan hukum dalam pengertian materiil. Hal tersebut didasarkan Putusan Mahkmah Konstitusi yang telah memutuskan bahwa frasa Penjelasan pasal 2 ayat (1), yaitu "dimaksud dengan 'secara melawan hukum' dalam pasal ini mencakup perbuatan melawan hukum dalam arti formil maupun arti materiil, yaitu meskipun perbuatan tersebut tidak diatur dalam peraturan perundang-undangan, namun apabila perbuatan tersebut dianggap tercela karena tidak sesuai dengan perasaan keadilan atau normanorma kehidupan sosial dalam masyarakat, maka perbuatan tersebut dapat dipidana" bertentangan dengan Undang-undang Dasar Negara Republik Indonesia Tahun 1945 serta menyatakan tidak mempunyai kekuatan hukum mengikat
\end{abstract}

Kata Kunci : Melawan Hukum, Korupsi, Tindak Pidana.

1 Dosen Fakultas Hukum Universitas Mataram. 


\section{A. PENDAHULUAN}

Berbicara tentang korupsi memang tidak pernah ada putusnya. Fenomena ini memang sangat menarik untuk dikaji, apalagi dalam situasi seperti sekarang ini, dimana ada indikasi yang mencerminkan ketidakpercayaan rakyat terhadap pemerintah. Tuntutan akan pemerintahan yang bersih semakin keras, menyusul krisisi ekonomi akhirakhir ini. Hal ini sungguh masuk akal, sebab kekacauan ekonomi saat ini merupakan ekses dari buruknya kinerja pemerintahan di Indonesia dan praktik korupsi inilah yang menjadi akar masalah. ${ }^{1}$

Korupsi merupakan perbuatan tercela dan bentuk dari penyakit sosial masyarakat, sehingga korupsi dikategorikan sebagai suatu tindak pidana (Straafbaarfeit). Perkara tindak pidana korupsi merupakan perkara yang dapat digolongkan ke dalam suatu kejahatan yang disebut dengan "white collor crime" yaitu kejahatan yang dilakukan oleh orang yang mempunyai kedudukan yang tinggi dalam masyarakat dan dilakukan sehubungan dengan tugas atau pekerjaannya. ${ }^{2}$

Pada waktu digulirkannya reformasi ada suatu keyakinan bahwa peraturan perundangan yang dijadikan landasan untuk memberantas korupsi dipandang tidak sesuai lagi dengan kebutuhan masyarakat. Setelah disahkan dan diundangkan beberapa peraturan perundang-undangan sebagai landasan hukum untuk melakukan pencegahan dan penindakan tindak pidana korupsi. Upaya tersebut diawali dengan berlakunya Undang-Undang Nomor 28 Tahun 1999 tentang Penyelenggaran Negara yang Bersih dan Bebas dari Korupsi, Kolusi dan Nepotisme. Konsideran UndangUndang tersebut menjelaskan bahwa praktek korupsi, kolusi dan nepotisme tidak hanya dilakukan antara Penyelenggara Negara melainkan juga antara Penyelenggara Negara dengan pihak lain.

Perbaikan di bidang legislasi juga diikuti dengan diberlakukannya Undang-Undang Nomor 31 Tahun 1999 sebagai penyempurnaan atas Undang-Undang Nomor 3 Tahun1971 tentang pemberantasan Tindak Pidana Korupsi. Konsideran Undang-Undang tersebut secara tegas menyebutkan bahwa tindak pidana korupsi sangat merugikan Keuangan Negara atau Perekonomian Negara dan menghambat pembangunan sosial, sehingga harus diberantas dalam rangka mewujudkan masyarakat adil dan makmur berdasarkan Pancasila dan Undang-Undang Dasar 1945. Tahun 2001, Undang-Undang Nomor 31 Tahun1999 disempurnakan kembali dan diubah dengan Undang-Undang Nomor $20 \quad$ Tahun 2001. Penyempurnaan ini dimaksud untuk lebih menjamin kepastian hukum, menghindari keragaman penafsiran hukum dan memberikan perlindungan terhadap hak-hak sosial dan ekonomi masyarakat, serta perlakuan yang adil dalam memberantas tindak pidana korupsi.

Menyadari kompleksnya permasalahan korupsi di tengah-tengah

\footnotetext{
${ }^{1}$ Adrian Sutendi. Hukum Keuangan Negara. Jakarta: Sinar Grafika, 2010, Hal. 189.

2 Darwan Prinst, Pemberantasan Tindak Pidana Korupsi. Bandung. PT. Citra Aditya Bakti. 2002. Hal. 2.
} 
krisis ekonomi serta ancaman yang nyata yang pasti akan terjadi, yaitu dampak dari kejahatan ini. Maka tindak pidana korupsi dapat dikategorikan sebagai permasalahan nasional yang harus dihadapi secara sungguhsungguh melalui keseimbangan langkah-langkah yang tegas dan jelas dengan melibatkan semua potensi yang ada dalam masyarakat khususnya pemerintah dan aparat penegak hukum. $^{3}$

Berdasarkan pemikiran diatas, timbul keinginan penyusun untuk melakukan penelitian ini. Hal ini dikarenakan di dalam kehidupan masyarakat banyak terjadi kecurangankecurangan dan ketimpanganketimpangan dalam kehidupan hukum dan kehidupan sosial lainnya, kenyataan tersebut menurut azas keadilan dan kepatutan tidak dapat ditolerir.

\section{B. PEMBAHASAN}

\section{Sifat Melawan Hukum Dalam Tindak Pidana Korupsi.}

Dalam Undang-Undang Dasar Negara Kesatuan Republik Indonesia 1945 ditegaskan bahwa negara Indonesia berdasarkan atas hukum (rechstaat), bukan berdasarkan kekusaan semata/belaka (machstaat). Ini berarti bahwa Republik Indonesia adalah negara hukum yang demoksratis berdasarkan pancasila dan UUD NKRI 1945, pemerintah menjalankan pemerintahannya berdasarkan aturan yang berlaku, menjunjung tinggi hak asasi manusia dan menjamin semua warga negara bersamaan kedudukannya di dalam hukum

${ }^{3}$ Evi Hartanti. Tindak Pidana Korupsi. Jakarta , Sinar Grafika. 2005.

${ }^{4}$ Evi Hartanti, Tindak Pidana Korupsi, Edisi Ke-2, Sinar Grafika, Jakarta, 2008, Hal. 1.

${ }^{5}$ Muhammad Rizal, dkk. Analisis Yuridis Mengenai Unsur Melawan Hukum Dalam Putusan Bebas Perkara Tindak dan pemerintahan serta wajib menjunjung tinggi hukum dan pemerintahan itu dengan tidak ada kecualinya. ${ }^{4}$

Tindak pidana korupsi merupakan salah satu bagian dari hukum pidana khusus (ius singulare, ius speciale atau bijzonder strafrecht) dengan ketentuan hukum positif (ius constitutum) yang diatur dalam Undang-Undang Nomor 31 Tahun 1999 Tentang Pemberantasan Tindak Pidana Korupsi Jo. Undang-Undang Nomor 20 Tahun 2001 tentang Perubahan Atas Undang-Undang Nomor 31 Tahun 1999 tentang Pemberantasan Tindak Pidana Korupsi selanjutnya disebut UUTPK. ${ }^{5}$

Melawan hukum artinya meskipun perbuatan tersebut tidak diatur dalam peraturan perundang-undangan (melawan hukum formil) namun apabila perbuatan tersebut dianggap tercela karena tidak sesuai dengan rasa keadilan atau normanorma kehidupan sosial dalam masyarakat (melawan hukum materil) maka perbuatan tersebut dapat dipidana. Pembentuk undang-undang menjadikan sifat melawan hukum sebagai unsur yang tertulis. Tanpa unsur ini, rumusan undang-undang akan menjadi terlampau luas. Sifat ini juga dapat dicela kadang-kadang dimasukkan dalam rumusan delik culpa.

Untuk menentukan apakah suatu perbuatan dikatakan perbuatan melawan hukum diperlukan unsur-unsur : ${ }^{6}$

a) Perbuatan tersebut melawan hukum;

b) Harus ada kesalahan pada pelaku;

c) Harus ada kerugian

Sifat melawan hukum memiliki kedudukan yang penting dalam hukum pidana di samping asas Legalitas. Ajaran ini

Pidana Korupsi Pembangunan Jalan Lingkar Manyar Banyuwangi (Putusan Nomor. 596/pid.b/2009/pn.bwi ), Artikel Ilmiah, Jember, 2013. Hal. 4.

6 Theodorus M. Tuanakotta. Menghitung Kerugian Keuangan Negara Dalam Tindak Pidana Korupsi. Jakarta: Salemba Empat, 2009, Hal. 73.

[Sifat Melawan Hukum Dalam...] | Idi Amin 
terdiri dari ajaran sifat melawan hukum yang formal dan materiil, antara lain $:^{7}$

a) Ajaran Sifat Melawan Hukum Formal.

Sifat melawan hukum formal terjadi karena memenuhi rumusan delik undang undang. Sifat melawan hukum formal merupakan syarat untuk dapat dipidananya perbuatan. Ajaran sifat melawan hukum formal adalah apabila suatu perbuatan telah memenuhi semua unsur yang termuat dalam rumusan tindak pidana, perbuatan tersebut adalah tindak pidana. Jika ada alasan-alasan pembenar maka alasan-alasan tersebut harus juga disebutkan secara tegas dalam undang-undang.

b) Ajaran Sifat Melawan Hukum Materiil. Sifat melawan hukum materiil merupakan suatu perbuatan melawan hukum yang tidak hanya terdapat di dalam undang-undang (yang tertulis), tetapi harus dilihat berlakunya asas-asas hukum yang tidak tertulis juga. Sifat melawan hukum itu dapat dihapuskan berdasar ketentuan undang-undang maupun aturan-aturan yang tidak tertulis

Masalah korupsi terkait dengan berbagai kompleksitas masalah, antara lain, masalah moral/sikap mental, masalah pola hidup dan budaya serta lingkungan sosial, masalah kebutuhan/tuntutan ekonomi dan kesenjangan sosial ekonomi, masalah struktur/sistem ekonomi, masalah sistem/budaya politik, masalah mekanisme pembangunan dan lemahnya birokrasi/prosedur administrasi (termasuk sistem pengawasan) dibidang keuangan dan pelayananan publik.

Berbagai jenis tindak pidana korupsi tidak seluruhnya mengandung rumusan "secara melawan hukum". Dalam sistem perundang-undangan hukum pidana yang berlaku sekarang, ternyata bersifat melawan hukum dari suatu tindakan tidak selalu dicantumkan sebagai salah satu unsur delik.

7 Teguh Prasetyo dan Abdul Hakim Barkatullah. Politik Hukum Pidana Kajian Kebijakan Kriminalisasai dan Deskriminalisasi. Yogyakarta : Pustaka Pelajar, . 2005, Hal. 3435.
Timbul persoalan, apakah sifat melawan hukum harus selalu dianggap sebagai salah satu unsur delik, walaupun tidak dirumuskan secara tegas, ataukah baru dipandang unsur dari suatu delik apabila dengan tegas dirumuskan dalam delik, selanjutnya dinyatakan bahwa secara formal atau secara perumusan undangundang suatu tindakan bersifat melawan hukum apabila melanggar atau bertentangan dengan ketentuan undangundang. Semua tindakan yang bertentangan dengan undang-undang atau memenuhi perumusan delik dalam undang-undang, baik sifat melawan hukum itu dirumuskan ataupun tidak merupakan tindakan yang bersifat melawan hukum. Sifat melawan hukum itu hanya akan hilang atau ditiadakan apabila dasar-dasar peniadaannya ditentukan dalam undangundang. ${ }^{8}$

Unsur melawan hukum dalam meliputi melawan hukum formil dan materiil. Ditentukan dalam Pasal 2 beserta penjelasannya, parameter melawan hukum formil adalah bertentangan dengan peraturan perundang-undangan, sedangkan parameter melawan hukum materil adalah bertentangan dengan nilai kepatutan dan keadilan masyarakat. ${ }^{9}$

Suatu perbuatan dikatakan melawan hukum secara formil adalah apabila perbuatan itu bertentangan dengan ketentuan undang-undang (hukum tertulis). Dengan pengertian seperti itu, maka suatu perbuatan bersifat melawan hukum adalah apabila telah terpenuhi semua unsur yang disebut di dalam rumusan delik. Jika semua unsur tersebut telah terpenuhi, maka tidak perlu lagi diselidiki apakah perbuatan itu menurut masyarakat benar-benar telah dirasakan sebagai prbuatan yang tidak patut dilakukan.

Sedangkan dalam pengertian melawan hukum secara materiil, suatu

\footnotetext{
8 J.C.T Simorangkir, dkk. Kamus Hukum. Jakarta : Sinar Grafika, 2000, Hal. 161.

${ }^{9}$ Nur Basuki Minarno, Penyalahgunaan Wewenang dan Tindak Pidana Korupsi dalam Pengelolaan Keuangan Daerah, Laksbang Mediatama, Surabaya, 2010, Hal. 186.
} 
perbuatan disebut sebagai perbuatan melawan hukum tidaklah hanya sekedar bertentangan dengan ketentuan hukum yang tertulis saja. Di samping memenuhi syaratsyarat formil, yaitu memenuhi semua unsur yang disebut dalam rumusan delik, perbuatan haruslah benar-benar dirasakan masyarakat sebagai perbuatan yang tidak boleh atau tidak patut dilakukan. Jadi dalam konstruksi yang demikian, suatu perbuatan dikatan sebagai melawan hukum adalah apabila perbuatan tersebut dipandang tercela dalam suatu masyarakat. ${ }^{10}$

Ukuran untuk mengatakan suatu perbuatan melawan hukum secara materiil bukan didasarkan pada ada atau tidaknya ketentuan dalam suatu Undang-Undang, akan tetapi di tinjau dari nilai yang ada dalam masyarakat. Pandangan yang menitikberatkan melawan hukum secara formil cenderung melihatnya dari sisi objek atau perbuatan pelaku. Artinya, apabila perbuatannya telah cocok dengan rumusan tindak pidana yang didakwakan, maka tidaklah perlu diuji apakah perbuatn itu melawan hukum secara materiil atau tidak.Sebaliknya secara materiil, merupakan pandangan yang menitikberatkan melawan hukum dari segi subjek atau pelaku. Dari sisi ini, apabila perbuatan telah cocok dengan rumusan tindak pidana yang didakwakan, maka tindakan selanjutnya adalah perlu dibuktikan ada atau tidaknya perbuatan melawan hukum secara materiil dari diri si pelaku. $^{11}$

Sehubungan dengan pembuktian unsur melawan hukum secara materiil, patut diperhatikan bahwa penerapan ajaran sifat melawan hukum materiil itu senantiasa tidak boleh melebihi syarat yang telah ditentukan melaui fungsi negatif saja.
Meskipun suatu perbuatan pelaku terbukti melawan hukum secara formil, namun apabila ditemukan adanya alasan-alasan yang meniadakan pidananya dengan suatukonstruksi yang "materielewederrechtelijk", maka si pelaku selayaknya dilepaskan dari segala tuntutan hukum. ${ }^{12}$

Sifat melawan hukum dapat ditemukan sebagai salah satu unsur tindak pidana korupsi dalam Pasal 2 UndangUndang No. 31 Tahun 1999 jo UndangUndang No. 20 Tahun 2001 tentang Pemberantasan Tindak Pidana Korupsi. Dalam kaitan dengan Undang-undang Pemberantasan Tindak Pidana Korupsi, hanya terdapat pada dua ketentuan, yaitu Pasal 2 ayat (1) dan Pasal 12 huruf e.

Pasal 2 ayat (1) Undang-undang No.31 Tahun 1999 jo Undang-Undang No. 20 Tahun 2001, menyatakan bahwa : "Setiap orang yang secara melawan hukum melakukan perbuatan memperkaya diri sendiri atau orang lain atau suatu korporasi yang dapat merugikan keuangan negara atau perekonomian negara, dipidana penjara dengan penjara seumur hidup atau pidana penjara paling singkat 4 (empat) tahun dan paling lama 20 (dua puluh) tahun dan denda paling sedikit Rp.200.000.000,00 (dua ratus juta rupiah) dan paling banyak Rp. 1.000.000.000,00 (satu milyar rupiah)."

Pasal 12 huruf e Undang-undang No. 31 Tahun 1999 menyatakan bahwa : "Pegawai negeri atau penyelenggara negara yang dengan maksud menguntungkan diri sendiri atau orang lain secara melawan hukum, atau dengan menyalahgunakan kekuasaannya memaksa seseorang memberikan sesuatu membayar, atau menerima pembayaran dengan potongan,

11 Loebby Loqman, Beberapa Ikhwal di Dalam Undang-Undang Nomor 3 tahun 1971 Tentang Pemberantasan Tindak pidana Korupsi, Datacom, Jakarta, 1991, Hal. 25.

12 H. Elwi Danil, Op.Cit., Hal. 144
${ }^{10}$ H. Elwi Danil, Korupsi : Konsep, Tindak Pidana, Dan Pemberantasannya, Raja Grafindo Persada, Jakarta, 2012, 
atau untuk mengerjakan sesuatu bagi dirinya sendiri,".

Kata melawan hukum dalam pasal tersebut kemudian dalam penjelasanya, mencakup perbuatan melawan hukum dalam arti formil maupun dalam arti materil, yakni meskipun perbuatan tersebut tidak diatur dalam peraturan perundangundangan, namun apabila perbuatan tersebut dianggap tidak tercela karena tidak sesuai dengan rasa keadilan atau norma kehidupan sosial dalam masyarakat, maka perbuatan tersebut dapat dipidana.

Leden Marpaung menyatakan bahwa pendapat para pakar mengenai secara melawan hukum sebagai unsur delik atau bukan, tidak ada kata sepakat atau tidak tidak bulat, sebagian berpendapat, apabila pada rumusan suatu delik dimuat unsur secara melawan hukum, unsur tersebut harus dibuktikan, dan sebaliknya apabila tidak dirumuskan, tidak perlu dibuktikan. Hal ini merupakan pendapat yang menganut paham formal. Berbeda dengan yang menganut paham materiil, yang menyatakan bahwa meskipun tidak dirumuskan, unsur melawan hukum perlu dibuktikan. ${ }^{13}$

Bagi para sarjana yang menganut pandangan formal mengenai sifat melawan hukum dalam hubungannya dengan perumusan suatu delik, apabila bersifat melawan hukum tidak dirumuskan dalam suatu delik, tidak perlu lagi diselidiki tentang bersifat melawan hukum. Sedangkan jika bersifat melawan hukum ini dicantumkan dalam rumusan delik, maka bersifat melawan hukum itu harus diselidiki. Dan dalam rangka penuntutan/mengadili harus terbukti bersifat melawan hukum tersebut. Justru dicantumkannya bersifat melawan hukum tersebut dalam norma delik, menghendaki penelitian apakah tindakan ini bersifat melawan hukum atau tidak. Demikianlah antara lain pendapat Simons dan para

13 Leden Marpaung. Asas-Teori-Praktik Hukum Pidana. Jakarta : Sinar Grafika, 2005, Hal. 46. pengikut ajaran formal. Sebaliknya para sarjana berpandangan material tentang bersifat melawan hukum, mengatakan bahwa sifat melawan hukum, selalu dianggap ada dalam setiap delik dengan tegas dirumuskan. Penganut teori ini mengemukakan bahwa pengertian dari hukum yang merupakan salah satu kata yang terdapat dalam bersifat melawan hukum, tidak hanya didasarkan kepada undang-undang saja, tetapi kepada yang lebih luas lagi, yaitu asas-asas umum yang berlaku sebagai hukum. Dengan perkataan lain bersifat melawan hukum berarti harus dapat dirasakan sebagai tidak boleh terjadi, bertentangan dengan kepatutan yang terdapat dalam masyarakat. Atau lebih tepat jika diartikan dengan tidak boleh terjadi dalam rangka pengayoman hukum dan perwujudan cita-cita masyarakat. ${ }^{14}$

Kerangka argumentasi seperti ini, maka persoalan sifat melawan hukum dimaknai secara formil ataukah materiil dalam fungsi negatif dan positif hanya berlaku pada ketentuan Pasal 2 ayat (1) dan Pasal 12 huruf e Undang-undang No. 31 tahun 199 Tentang Pemberantasan Tindak Pidana Korupsi. Ketentuan Undang-undang selain kedua di atas dengan pertimbangan perbuatan-perbuatan yang sesuai dengan istilah yang dipergunakan dalam rumusan pasal dengan sendirinya terlarang karena melawan hukum.

Apabila dibandingkan dengan rumusan melawan hukum dalam KUHP maupun Yurisprudensi MA, rumusan dalam UU No. 31 tahun 1999 memiliki makna yang dapat dikatakan berbeda, setidaknya jika dikaitkan dengan Penjelasan Undangundang No. 31 Tahun 1999 tentang Tindak Pidana Korupsi yang dimaksud, yaitu Pasal 2 ayat (1). Secara lengkap, Pasal 2 UU No. 31 tahun 1999 rumusannya sebagai berikut

(1) Setiap orang yang secara melawan hukum melakukan perbuatan

14 Tjandra Sridjaja Pradjonggo, Sifat Melawan Hukum Dalam Tindak Pidana Korupsi, Indonesia Lawyer Club, Jakarta, 2010. Hal. 166. 
memperkaya diri sendiri atau orang lain atau suatu korporasi yang dapat merugikan keuangan negara atau perekonomian negara, dipidana penjara paling singkat 4 (empat) tahun paling lama 20 (dua puluh) tahun dan denda paling sedikit Rp. 200.000.000,00 (dua ratus juta rupiah) dan paling banyak Rp. 1.000.000.000,00 (satu milyar rupiah).

(2) Dalam hal tindak pidana korupsi sebagaimana dimaksud dalam ayat (1) dilakukan dalam keadaan tertentu, pidana mati dapat dijatuhkan

Berdasarkan Pasal 2 ayat (1) tersebut oleh pembentuk undang-undang diberi penjelasan, khususnya menyangkut makna unsur melawan hukum, namun kemudian dicabut oleh Mahkamah Konstitusi melalui Putusan Nomor 003/PUU-IV/2006 tanggal 25 Juli 2006. Penjelasan tersebut meskipun secara yuridis dianggap sudah tidak ada, tetapi perlu dikemukakan sekedar untuk memahami secara kesejarahan makna sifat melawan hukum tersebut dalam Undang-undang No. 31 Tahun 1999.

Penerapan melawan hukum materiil pada masa berlakunya Undang-Undang No. 31 Tahun 1999 dan Undang-Undang No. 20 Tahun 2001 dijadikan dalam satu pokok pembahasan dikarenakan pada masa berlakunya Undang-Undang No. 31 Tahun 1999 tidak diketemukan yurisprudensi Mahkamah Agung mengenai kasus korupsi, sebagian besar perkara yang diputus adalah kasus-kasus kepailitan. Hal ini sangat wajar mengingat pada tahun 1998 hingga 2000 merupakan tahun terjadinya krisis moneter, sehingga banyak usaha yang pailit, oleh karena itu pembahasan dua periode itu dijadikan satu tanpa mengurangi substansi pembahasan dikarenakan dalam Undang-
Undang No. 21 Tahun 2001 juga tidak terdapat perubahan substansi perumusan tindak pidana korupsi, hanya penyempurnaan dan hukum acara formil yang lebih komprehensif. ${ }^{15}$

Melalui Putusan Mahkamah

Konstitusi Nomor 003/PUU-IV/2006 inilah rumusan penjelasan Pasal 2 ayat (1) Undang-Undang No. 31 Tahun 1999 dibatalkan oleh Mahkamah Konstitusi sehingga tidak memiliki kekuatan mengikat lagi. Hal ini didasarkan bahwa Pasal 2 ayat (1) Undang-Undang No. 31 Tahun 1999 dianggap bertentangan dengan Pasal $28 \mathrm{D}$ ayat (1) UUD 1945.

Penjelasan Pasal 2 ayat (1) dalam kaitannya dengan unsur melawan hukum menegaskan bahwa : "yang dimaksud dengan secara melawan hukum dalam Pasal ini mencakup perbuatan melawan hukum dalam arti formil maupun dalam arti materiil, yaitu meskipun perbuatan tersebut tidak diatur dalam peraturan perundangundangan, namun apabila perbuatan tersebut dianggap tercela karena tidak sesuai dengan rasa keadilan atau normanorma kehidupan sosial dalam masyarakat, maka perbuataan tersebut dapat dipidana".

Meskipun penjelasan Pasal 2 ayat (1) Undang-undang No. 31 Tahun 1999 dinyatakan oleh Mahkamah Konstitusi bertentangan dengan Undang-undang Dasar Republik Indonesia Tahun 1945 dan dinyatakan pula tidak mempunyai kekuatan hukum mengikat, namun pemaknaan dalam Penjelasan bagian Umum serta rumusan dalam Pasal 12 huruf e Undang-undang No. 31 Tahun 1999 tidak disinggung-singgung oleh Mahkamah Konstitusi atau tidak dinyatakan seperti halnya Penjelasan Pasal 2 ayat (1) Undang-undang No. 31 Tahun 1999. Hal ini secara prosedural atau hukum acara Mahkamah Konstitusi dapat
15 Dina Novita Sari, Pergeseran Ajaran Melawan Hukum Materii Dalam Tindak Pidana Korupsi Sejak
Berlakunya UU No. 24 Tahun 1960 Hingga UU No. 31 Tahun 1999 Jo. UU No. 20 Tahun 2001, Skripsi, Universitas Indonesia, Depok, Hal. 148. 
diargumentasikan dengan dalil bahwa hal tersebut tidak dimintakan oleh Pemohon, namun secara substansial hal itu berarti rumusan makna melawan hukum dalam Penjelasan bagian Umum dan Pasal 12 huruf e Undang-undang No. 31 Tahun 1999 masih dapat dimaknai berlaku. Kondisi tersebut secara kritis dapat terjadi karena kelalaian Mahkamah Konstitusi bahwa terdapat penjelasan serupa yang tertuang dalam Penjelasan bagian Umum.

Sebagai pembanding dalam Undang-Undang No. 3 Tahun 1971 dirumuskan dalam Pasal 1 ayat (1) huruf a : Dihukum karena tindak pidana korupsi : Barangsiapa dengan melawan hukum melakukan perbuatan memperkaya diri sendiri atau orang lain atau suatu badan yang secara langsung atau tidak langsung merugikan keuangan negara dan atau perekonomian negara, atau diketahui atau patut disangka olehnya bahwa perbuatanperbuatan tersebut merugikan keuangan negara atau perekonomian negara. ${ }^{16}$

Penjelasan UU 3/1971 dalam kaitan dengan unsur melawan hukum menegaskan bahwa : Dengan mengemukakan sarana "melawan hukum" yang mengandung pengertian formal maupun material, maka dimaksudkan agar supaya lebih mudah memproleh pembuktian tentang perbuatan yang dapat dihukum, yaitu 'memperkaya diri sendiri atau orang lain atau suatu badan', daripada memenuhi ketentuan untuk membuktikan lebih dahulu adanya kejahatan/pelanggaran seperti diisyaratkan oleh Undang-undang Nomor 24 Prp. Tahun $1960 .{ }^{17}$

\section{Undang-Undang No. 3 Tahun 1971} tidak memberikan penjelasan lebih jauh menyangkut melawan hukum dalam pengertian materiil tersebut. Yurisprudensi MA juga masih sebatas menginterprestasikan pada konsepsi sifat melawan hukum dalam pengertian materiil dalam fungsinya yang negatif. Bahkan Penjelasan Pasal 1 huruf a Undang-Undang
No. 3 Tahun 1971 menyebutkan bahwa "Ayat ini tidak menjadikan perbuatan melawan hukum sebagai suatu perbuatan yang dapat dihukum, melainkan melawan hukum ini merupakan sarana untuk melakukan perbuatan yang dapat dihukum, yaitu memperkaya diri sendiri atau orang lain atau suatu badan......".

Pembedaan antara sifat melawan hukum secara umum dan khusus, secara formal dan materiil, maka dapat dikatakan bahwa kategori sifat melawan hukum yang dipakai oleh Pasal 2 ayat (1) dan Pasal 12 huruf e Undang-undang No. 31 tahun 1999, yaitu sifat melawan hukum khusus dan dalam pengertian materiil. Maksud melawan hukum secara khusus, yaitu Pasal 2 ayat (1) dan Pasal 12 huruf e Undangundang No. 31 Tahun 1999 yang secara tegas mencantumkan "melawan hukum" sebagai bagian inti atau bestanddeel tindak pidana. Dengan sendirinya "melawan hukum" tersebut harus tercantum di dalam surat dakwaan, sehingga harus dapat dibuktikan, putusannya ialah bebas. ${ }^{18}$

Melawan hukum dalam pengertian materiil, secara konsepsional dibedakan antara melawan hukum dalam pengertian materiil yang positif dan negatif. Pasal 2 Undang-undang No. 31 Tahun 1999 sebelum adanya Putusan Mahkamah Konstitusi Nomor 003/PUU-IV/2006 tampaknya menganut ajaran sifat melawan hukum, baik dalam pengertian formil maupun materiil. Sifat melawan hukum materiil tersebut, baik dalam fungsi yang negatif maupun positif. Fungsi positif dari sifat melawan hukum, yang kemudian dinyatakan tidak mempunyai kekuatan hukum mengikat oleh Mahkamah Konstitusi, yaitu meskipun peraturan perundang-undangan tidak mengatur, namun apabila perasaan keadilan dalam masyarakat, maupun norma-norma sosial menyatakan bahwa perbuatan tersebut

16 Tjandra Sridjaja Pradjonggo, Op.Cit. Hal. 172

17 Ibid. 
tercela, maka perbuatan tersebut dapat dipidana. ${ }^{19}$

Berdasarkan adanya Putusan Mahkamah Konstitusi No. 003/PUUIV/2006 Tahun 2006, maka secara konsepsional tentunya melawan hukum seperti diatur dalam Pasal 2 ayat (1) Undang-undang No. 31 Tahun 1999 hanya menganut ajaran sifat melawan hukum dalam pengertian materiil, yang bersifat negatif. Hal tersebut didasarkan Putusan Mahkmah Konstitusi yang telah memutuskan bahwa frasa Penjelasan pasal 2 ayat (1), yaitu "dimaksud dengan 'secara melawan hukum' dalam pasal ini mencakup perbuatan melawan hukum dalam arti formil maupun arti materiil, yaitu meskipun perbuatan tersebut tidak diatur dalam peraturan perundang-undangan, namun apabila perbuatan tersebut dianggap tercela karena tidak sesuai dengan perasaan keadilan atau norma-norma kehidupan sosial dalam masyarakat, maka perbuatan tersebut dapat dipidana" bertentangan dengan Undang-undang Dasar Negara Republik Indonesia Tahun 1945 serta menyatakan tidak mempunyai kekuatan hukum mengikat. ${ }^{20}$

Berdasarkan pandangan-pandangan yang berkembang dalam ilmu hukum pidana yang menunjukkan bahwa meskipun menganut atau menerima ajaran sifat melawan hukum dalam pengertian materiil, namun hendaknya diterapkan secara negatif-bukan positif. Sifat melawan hukum dalam pengertian materiil negatif juga sudah bertentangan dengan asas legalitas, khususnya aspek kepastian hukum, lebihlebih dalam pengertian materiil yang positif.

Unsur melawan hukum dalam Undang-undang Tindak Pidana Korupsi dengan demikian setelah muncul Putusan

19 Komariah Emong Sapardjaja, Ajaran Sifat Melawan Hukum Meteriil dalam Hukum Pidana Indonesia, Studi Kasus tentang penerapan dan perkembangannya dalam Yurisprudensi, Alumni, Bandung, 2002, halaman 127.
Mahkamah Konstitusi Nomor 003/PUUIV/2006 dapat diinterprestasikan dalam pengertian formil dan materiil dalam fungsi yang negatif. Apabila, Penjelasan bagian Umum Undang-undang Pemberantasan Tindak Pidana Korupsi mengenai melawan hukum masih dianggap berlaku, sesungguhnya undang-undang itu masih mengikuti ajaran sifat melawan hukum materiil dalam fungsi positif, di samping sifat melawan hukum formil dan materiil dalam fungsi negatif. ${ }^{21}$

\section{PENUTUP}

Berdasarkan pembahasan di atas, penulis mengambil kesimpulan sebagai berikut :

1. Berdasarkan adanya Putusan Mahkamah Konstitusi No. 003/PUU-IV/2006 Tahun 2006, maka secara konsepsional tentunya sifat melawan hukum seperti diatur dalam Pasal 2 ayat (1) Undangundang No. 31 Tahun 1999 hanya menganut ajaran sifat melawan hukum dalam pengertian materiil, yang bersifat negatif. Hal tersebut didasarkan Putusan Mahkmah Konstitusi yang telah memutuskan bahwa frasa Penjelasan pasal 2 ayat (1), yaitu "dimaksud dengan 'secara melawan hukum' dalam pasal ini mencakup perbuatan melawan hukum dalam arti formil maupun arti materiil, yaitu meskipun perbuatan tersebut tidak diatur dalam peraturan perundangundangan, namun apabila perbuatan tersebut dianggap tercela karena tidak sesuai dengan perasaan keadilan atau norma-norma kehidupan sosial dalam masyarakat, maka perbuatan tersebut dapat dipidana" bertentangan dengan Undang-undang Dasar Negara Republik

20 Tjandra Sridjaja Pradjonggo, Op. Cit., Hal. 178.

${ }^{21}$ Ibid. Hal. 179. 
Indonesia Tahun 1945 serta menyatakan tidak mempunyai kekuatan hukum mengikat

\section{DAFTAR PUSTAKA}

Danil, H. Elwi. Korupsi : Konsep, Tindak Pidana, Dan Pemberantasannya, Raja Grafindo Persada, Jakarta, 2012.

Hartanti, Evi. Tindak Pidana Korupsi, Edisi Ke-2, Sinar Grafika, Jakarta, 2008,

Tindak Pidana Korupsi. Jakarta , Sinar Grafika. 2005.

Loqman, Loebby. Beberapa Ikhwal di Dalam Undang-Undang Nomor 3 tahun 1971 Tentang Pemberantasan Tindak pidana Korupsi, Datacom, Jakarta, 1991.

Marpaung, Leden. Asas-Teori-Praktik Hukum Pidana. Jakarta : Sinar Grafika, 2005.

Minarno, Nur Basuki. Penyalahgunaan Wewenang dan Tindak Pidana Korupsi dalam Pengelolaan Keuangan Daerah, Laksbang Mediatama, Surabaya, 2010

Pradjonggo, Tjandra Sridjaja. Sifat Melawan Hukum Dalam Tindak Pidana Korupsi, Indonesia Lawyer Club, Jakarta, 2010

Prasetyo, Teguh dan Abdul Hakim Barkatullah. Politik Hukum Pidana Kajian Kebijakan Kriminalisasai dan Deskriminalisasi. Yogyakarta : Pustaka Pelajar. 2005.
Prinst, Darwan. Pemberantasan Tindak Pidana Korupsi. Bandung. PT. Citra Aditya Bakti. 2002.

Rizal, Muhammad dkk. Analisis Yuridis Mengenai Unsur Melawan Hukum Dalam Putusan Bebas Perkara Tindak Pidana Korupsi Pembangunan Jalan Lingkar Manyar Banyuwangi (Putusan Nomor. 596/pid.b/2009/pn.bwi ), Artikel Ilmiah, Jember, 2013.

Sapardjaja, Komariah Emong. Ajaran Sifat Melawan Hukum Meteriil dalam Hukum Pidana Indonesia, Studi Kasus tentang penerapan dan perkembangannya dalam Yurisprudensi, Alumni, Bandung, 2002.

Sari, Dina Novita. Pergeseran Ajaran Melawan Hukum Materii Dalam Tindak Pidana Korupsi Sejak Berlakunya UU No. 24 Tahun 1960 Hingga UU No. 31 Tahun 1999 Jo. UU No. 20 Tahun 2001, Skripsi, Universitas Indonesia, Depok. 2002.

Simorangkir, J.C.T dkk. Kamus Hukum. Jakarta : Sinar Grafika, 2000.

Sutendi, Adrian. Hukum Keuangan Negara. Jakarta: Sinar Grafika, 2010

Tuanakotta, Theodorus M. Menghitung Kerugian Keuangan Negara Dalam Tindak Pidana Korupsi. Jakarta: Salemba Empat, 2009.

\section{Perundang-Undangan}

Indonesia, Undang-Undang No. 30 Tahun 1999 Jo. Undang-Undang No. 20 Tahun 2001 tentang Pemberantasan Tindak Pidana Korupsi. 
[JATISWARA

Putusan Mahkamah Konstitusi No. 003/PUU-IV/2006.

Peraturan Pemerintah Nomor 24 Tahun 1997 tentang Pendaftaran Tanah 